\title{
Recorregut de recerca geològica i mineralògica per la subcomarca del Lluçanès (comarca d'Osona): des d'Alboquers a Olost, Albars, Prats de Lluçanès i a Santa Maria de Merlés
}

Josep Maria Mata-Perelló

Joaquim Sanz Balagué

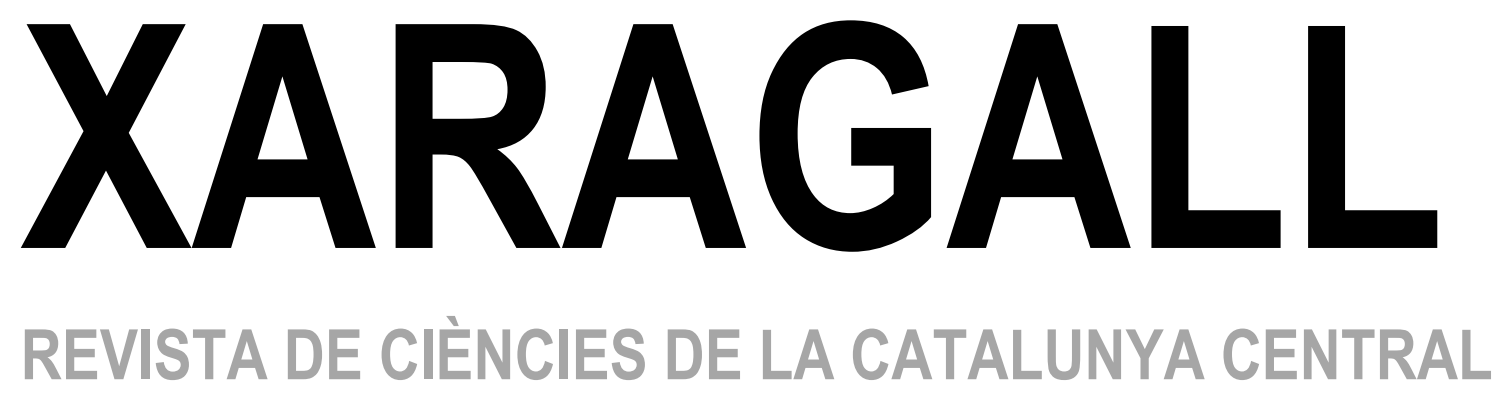

n. 5

MAIG 2014 


\title{
RECORREGUT DE RECERCA GEOLÒGICA I MINERALÒGICA PER LA SUBCOMARCA DEL LLUÇANĖS (COMARCA D'OSONA): DES D'ALBOQUERS A OLOST, ALBARS, PRATS DE LLUÇANĖS I A SANTA MARIA DE MERLÉS
}

\author{
Josep Maria Mata-Perelló \\ Museu de geologia Valentí Masachs, Escola Politècnica Superior d'Enginyeria de Manresa \\ (EPSEM), Universitat Politècnica de Catalunya · BarcelonaTech (UPC), 08272 Manresa, Spain
}

\section{Joaquim Sanz Balagué}

Departament d'Enginyeria Minera i Recursos Naturals (EMRN), Escola Politècnica Superior d'Enginyeria de Manresa (EPSEM), Universitat Politècnica de Catalunya - BarcelonaTech (UPC), 08272 Manresa, Spain

Paraules clau: Depressió geològica de l'Ebre; patrimoni miner; patrimoni geològic

\begin{abstract}
Resum
Itinerari realitzat el 27 d'abril de 2013. En aquesta ocasió, el recorregut de d'itinerari discorrerà, en la seva totalitat per la Depressió Geològica de l'Ebre (i més concretament, ho farà pel seu sector corresponent a la seva Depressió Central).

Tot i així, d'itinerari passarà per les proximitats d'alguns indrets més o menys replegats de l'esmentada depressió, tot i que en general aquests plecs no tenen gran desenvolupament. Malgrat això, cal fer esment del Sinclinal d'Olost, Cap a ponent, trobarem també I'Anticlinal de Puig - reig i el Sinclinal de Gironella, entre altres elements

Així, des del seu inici a la petita d'Alboquers (del municipi de Sant Bertomeu del Grau, al Lluçanès osonenc) fins a la seva fi, pels voltants de la localitat de santa Maria de Merlès, igualment situada a la subcomarca del Lluçanès (però en aquest cas dintre del Berguedà), totes les aturades del recorregut de d'itinerari, es trobaran ubicades dintre d'aquesta unitat geològica anteriorment esmentada.
\end{abstract}

Per d'altra banda, i com ja s'entreveu al títol, el recorregut de d'itinerari discorrerà per íntegrament per la subcomarca del Lluçanès, iniciant-se als sectors osonencs, per a finalitzar als situats dintre de l'actual comarca del Berguedà. 


\section{Objectius fonamentals}

Els objectius que s'esperen aconseguir en el transcurs d'aquest itinerari, es centraran, fonamentalment, en els següents aspectes:

1. S'observarà l'estructura de la Depressió Geològica de l'Ebre (i més concretament del seu sector de la Depressió Central), per la qual circularà quasi al llarg de tot el recorregut de l'itinerari, entre Alboquers, Olost, Prats de Lluçanès i Santa Maria de Merlès. Així, s'intentaran observar les diferents estructures representades en el recorregut, com les següents: el Sinclinal de Gironella, I'Anticlinal de Puig-reig, i el Sinclinal d'Olost entre altres elements estructurals.

2. Es reconeixeran els materials cenozoics que constitueixen el rebliment de la Depressió Central. per aquests indrets. Aquests materials, eminentment oligocènics (i eocènics), es reparteixen dintre del recorregut de d'itinerari, entre els afloraments que pertanyen a les següents unitats biostratigràfiques: Complex Al-luvial de Berga i Formació Solsona, fonamentalment.

3. Observació, per arreu de diferents exemples de relleus en costa, i de la seva disposició en funció de l'estructura de la zona, per la qual discorre aquest itinerari.

4. Observació de les explotacions mineres situades al llarg del recorregut de l'itinerari, com les situades a la Roca, prop de Perafita.

5. Observació dels impactes produïts per les explotacions mineres i de les restauracions dutes a terme, per tal d'aminorar els impactes.

6. Observació al llarg de tot el recorregut, de tots els elements relacionats amb el Patrimoni Geològic i Miner, de la subcomarca del Lluçanès. Entre aquests elements, cal parlar del paratge de les Goles de Fumanya, a Sant Martí d’Albars.

\section{Antecedents}

No coneixem cap antecedent relatiu al conjunt d'aquest itinerari. Hi ha un sol antecedent parcial nostre, relatiu als trams inicials del recorregut de l'itinerari. Hi ha, però, uns antecedents nostres, molt marginals: es tracta de Mata - Perelló (2013). Així, es pot considerar a l'actual itinerari com una primícia.

Com antecedents geològics de caire general, corresponents als trets geològics bàsics catalans, considerarem els treballs de: Guimerà et altri (1992), així com el de RIBA et altri (1976), referits al conjunt dels Països Catalans. Tanmateix farem esment del treball corresponent a I'IGME (1975).

Pel que fa als aspectes mineralògics d'aquest itinerari, farem esment d'un antecedent mineralògic general: Mata-Perelló (1991), referit al conjunt de Catalunya.

Tots aquests treballs, i d'altres, es trobaran relacionats a l'apartat dedicat a les referències bibliogràfiques, al qual ens remetem. 


\section{Recorregut de d'itinerari}

L'iniciï del recorregut de d'itinerari, es realitzarà per les immediacions de la petita localitat d'Alboquers (de l'actual municipi de Sant Bartomeu del Grau). Des d'aquí, per la carretera autonòmica $C-62$, el recorregut es dirigirà cap a la població d'Olost. En aquest tram es farà una fillola, per la carretera d'Oristà (la B - 433), fent-se una aturada prop de l'inici del trencall de la fillola. Després, el recorregut arribarà a Olost, des d'on es continuarà cap a ponent, fins arribar prop de Santa Creu dels Joglars. Abans, però, es trobarà el trencall per la dreta, que es dirigeix cap a Perafita: la carretera local BP 4653. Prop d'aquesta població es farà una nova aturada.

Tot seguit, en retornar a Santa creu de Joglars, ens caldrà agafar el trencall de Sant Martí d'Albars, la carretera BV - 434. En agafar-la, ens caldrà anar cap a les Goles de Fumanya, per on farem una nova aturada. Posteriorment, després de retornar a la carretera autonòmica $\mathrm{C}$ 62 (prop de la Santa Creu dels Joglars), caldrà anar cap a la capital comarcal, cap a Prats de Lluçanès. Entorn d'aquesta població es faran diverses aturades.

Després, per la carretera autonòmica $C-62$, ens caldrà anar cap a la cruïlla de carreteres de la Riera de Merlès, per tal de continuar per la carretera local BV - 4406, la qual ens aproparà cap a Santa Maria de Merlès, per on farem les darreres aturades del recorregut de l'itinerari, prop del Gorg Blau, per on finalitzarà el recorregut d'aquest itinerari.

\section{Advertiments previ}

Com en altres recorreguts de recerca geològica i mineralògica ..., si es disposa del temps suficient, poden efectuar-se passant per totes les parades i filloles. En cas contrari, recomanem prescindir de les anomenades parades - condicionals.

Com en altres recorreguts, recomanem demanar informació sobre l'estat dels camins, abans d'iniciar d'itinerari. En especial pels indrets on s'han d'efectuar trajectes per camins de terra. En aquest itinerari n'hi ha molt pocs. Un d'ells és I'accés a la Riera Gabarresa, prop de la població d'Albars.

Per d'altra banda, i en qualsevol cas, cal tenir sempre una cura molt especial de respecte a la natura, al llarg de tot el recorregut; de d'itinerari.

\section{Descripció de d'itinerari}

Com ja es habitual, s'estructurarà en una sèrie d'estacions (parades o aturades), en les qual es faran descripcions geològiques o mineralògiques, si s'escau. En cada cas s'indicarà el número del mapa topogràfic a escala 1:50.000 on es troba l'indret. En aquest cas, el recorregut de d'itinerari passarà pels fulls següents: 293 (o de Berga) i 331 (full de Navàs), de I'"Instituto Geográfico y Catastral" espanyol, a escala 1:50.000.

Així doncs, la relació i descripció de les aturades que composen aquest itinerari, és la següent: 


\subsection{Parada 1 - condicional. Collet de les Vaques, (terme municipal d'Oristà, comarca d'Osona, subcomarca del Lluçanès). (Full 331).}

El recorregut de l'itinerari el començarem dintre del municipi de Sant Bartomeu del Grau, situat al sector osonenc del Lluçanès. Així, el començarem per les immediacions del poblet escampat d'Alboquers (de l'antic terme de Gurb). Des d'aquest lloc, ens caldrà anar cap a la carretera autonòmica $C-62$, per tal de circular per ella en el seu sentit NW, anant cap a Olost. En arribar al trencall d'Oristà, d'on surt la carretera local que es dirigeix cap a quest darrer poble, la $\mathrm{B}$ 433), ens caldrà agafar-la. Poc després, en arribar al Collet de les Vaques, a poc més d'un Km de la cruïlla, farem la primera aturada, després de recórrer uns $10 \mathrm{Km}$ des de l'inici del recorregut.

La totalitat d'aquest recorregut I'hem fet dintre de la Depressió Geològica de l'Ebre o Conca de I'Ebre (per on discorrerà tot el recorregut de l'itinerari). Així, haurem trobat exclusivament afloraments dels materials cenozoics de l'Eocè i de I'Oligocè) Prop d'on hem iniciat el recorregut, hi ha afloraments de les calcolutites grises (margues de Vic) i de nivells de guixos (guixos de la Noguera), que no hem arribat a trobar, de l'Eocè. Així, nosaltres haurem vist afloraments de gresos i de de calcolutites rogenques, continentals, que podrien correspondre als materials de la Formació Artés, tot i que sovint son groguencs; son de l'Eocè - Oligocè. De vegades hi ha intercalacions de nivells de conglomerats. Aquests materials són els que apareixen a l'indret de la present aturada.

Des d'aquest indret, mirant cap el NNW, podem gaudir d'una bona visió dels relleus del Lluçanès $i$ fins $i$ tot dels del Berguedà. Així, en primer terme podem veure els afloraments dels materials cenozoics de la Depressió Geològica de l'Ebre, mentre que al fons podem veure els relleus mesozoics del Sistema Pirinenc, (concretament dels Rasos de Peguera i de la Serra de la Guàrdia), ja dintre del Berguedà (fotografia 1).

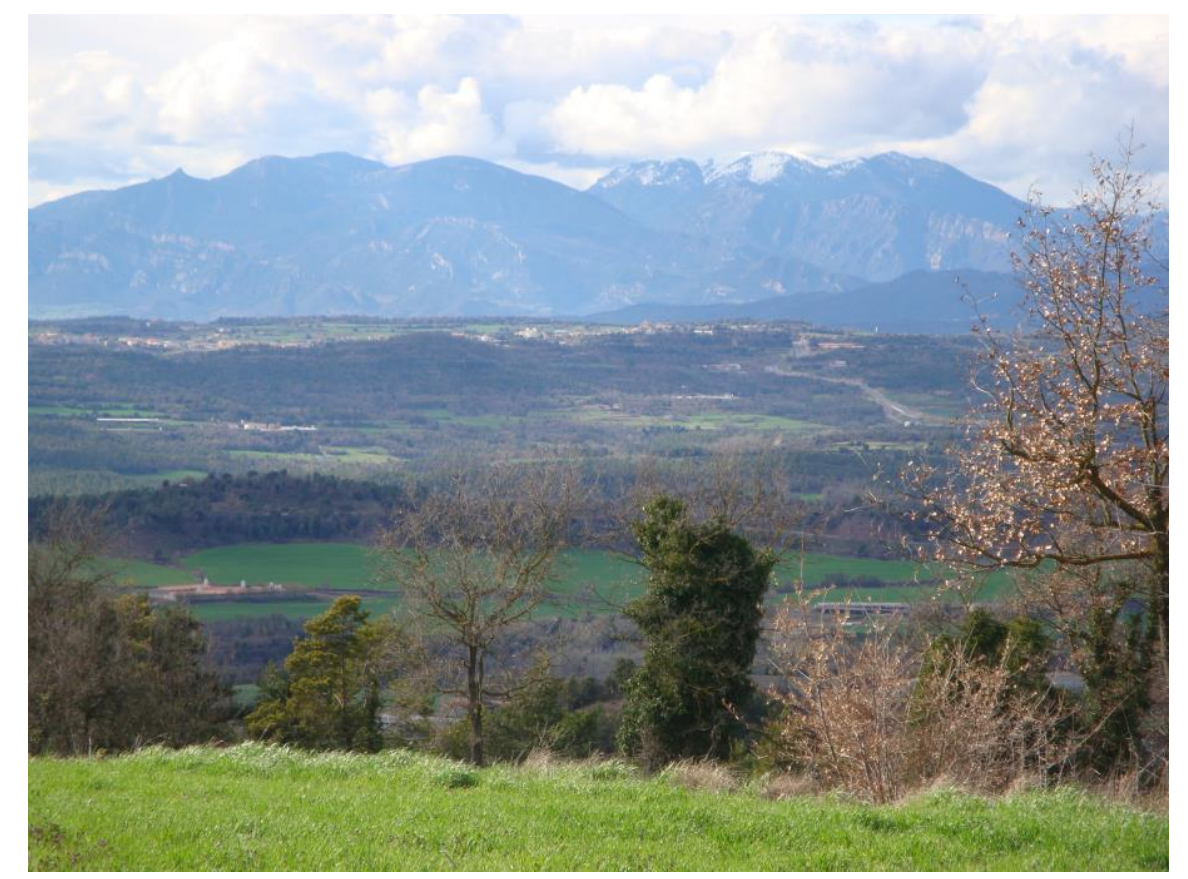

Fotografia 1. La Depressió Geològica de l'Ebre i el Sistema Pirinenc, des del Collet de les Vaques 


\subsection{Parada 2. Pedrera de la Roca, (terme municipal de Perafita, comarca d'Osona, subcomarca del Lluçanès). (Full 293).}

Després de realitzar l'aturada anterior, cal retornar cap a la carretera autonòmica catalana $C$ 62 , amb la finalitat d'arribar fins al poble d'Olost. Després de sobrepassar-lo, continuant cap a Prats de Lluçanès, arribarem al trencall d'on surt la carretera BP - 4653 (la qual es dirigeix cap al nord). Per aquesta carretera arribarem al poble de Perafita, amb la intenció de realitzar una fillola. A partir d'aquí, després de sobrepassar-lo lleugerament, ens caldrà anar cap a les immediacions de la Mare de Deu del Remei i cap el paratge de la Roca. Així arribarem a una pedrera en actiu, per on farem la present aturada, després d'un recorregut proper als $14 \mathrm{Km}$, des de la parada anterior.

En aquest recorregut, hem anat trobant afloraments dels materials esmentats a la parada anterior. Aquests materials pertanyen fonamentalment a l'Eocè Superior i a l'Oligocè. Així, haurem trobat afloraments dels nivells rogencs de la Formació Artés, amb gresos i calcolutites. Poc a poc han anat predominant les tonalitats ocres, que corresponen lateralment a la Formació Solsona.. Per d'altra banda, molt sovint, haurem vist nivells de gresos de gra gros i de conglomerats, pels indrets de la present aturada.

També cal dir, que en aquest trajecte hem estat circulant pel Sinclinal d'Olost; així, sovint haurem vist com els materials cabussen lleugerament cap al NE i en altres indrets els haurem vist com cabussen cap el SW, especialment pels voltants d'Olost. Aquest plec te una direcció WNW - ESE.

En aquest indret hi ha una explotació minera en actiu (per entrar-hi cal demanar el corresponent permís). Aquí s'exploten els nivells de gra gros dels gresos cenozoics (fotografia 2).

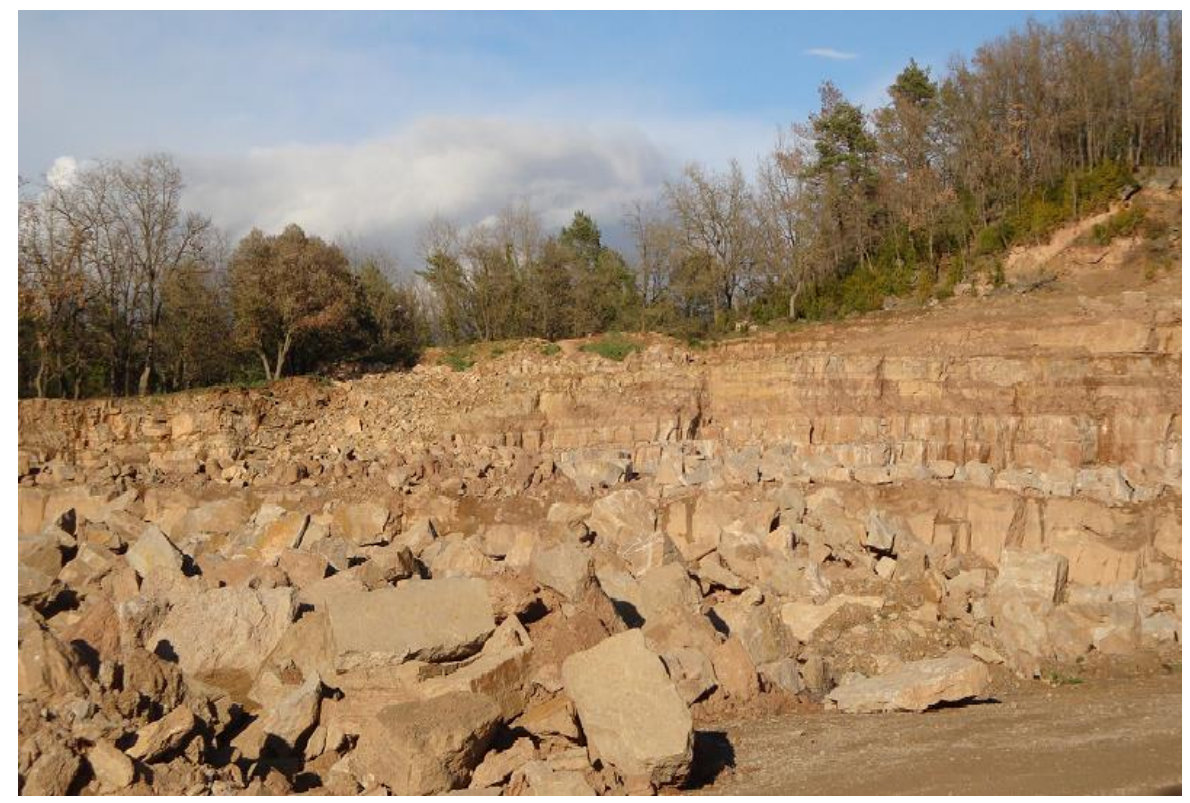

Fotografia 2. Un aspecte de la pedrera de la Roca, de Perafita. 


\subsection{Parada 3 . Goles de Fumanya, (terme municipal de Sant Martí d'Albars, comarca d'Osona, subcomarca del Lluçanès). (Full 293).}

Després de realitzar l'aturada anterior, cal retornar a la carretera autonòmica $C$ - 62, finalitzant la fillola que ens ha dut a l'explotació minera de Perafita. En arribar a la carretera autonòmica, ens convindrà continuar cap a Santa Creu de Joglar, des d'on iniciarem una altra fillola, anant cap el Nord per la carretera local BV - 4342, amb la finalitat d'arribar a les immediacions de la població de Sant Martí d'Albars. Tot i així, poc abans d'arribar-hi, trobarem un camí per l'esquerra que es dirigeix cap a Fumanya i cap al paratge de les Goles de Fumanya. Ens caldrà anar-hi, per tal de fer una nova parada en aquest indret. Així, des de l'anterior, haurem fet un recorregut d'uns $12 \mathrm{Km}$, per tal d'arribar fins aquí.

En aquest recorregut, hem anat trobant els materials esmentats a les aturades anteriors, els quals pertanyen al Cenozoic, especialment as trams superiors de l'Eocè i a I'Oligocè. Per d'altra banda, aquests materials es situen a la zona de transició entre la Formació Artés i la Formació Solsona. Aquests són els materials que apareixen a l'indret de la present aturada. Així, en aquest recorregut haurem trobat afloraments de gresos i de calcolutites, de tonalitats rogenques i ocres, segons els llocs. Tanmateix, en aquest trajecte haurem trobat i sobrepassat el Sinclinal d'Olost, del que hem parlat a l'aturada anterior.

En aquest indret es pot veure com la Riera Gabarresa es troba engorjada en travessar uns nivells potents de gresos, dels que hem parlat anteriorment. (fotografia 3). Aquest indret constitueix un important element del Patrimoni Geològic de la comarca del Lluçanès.

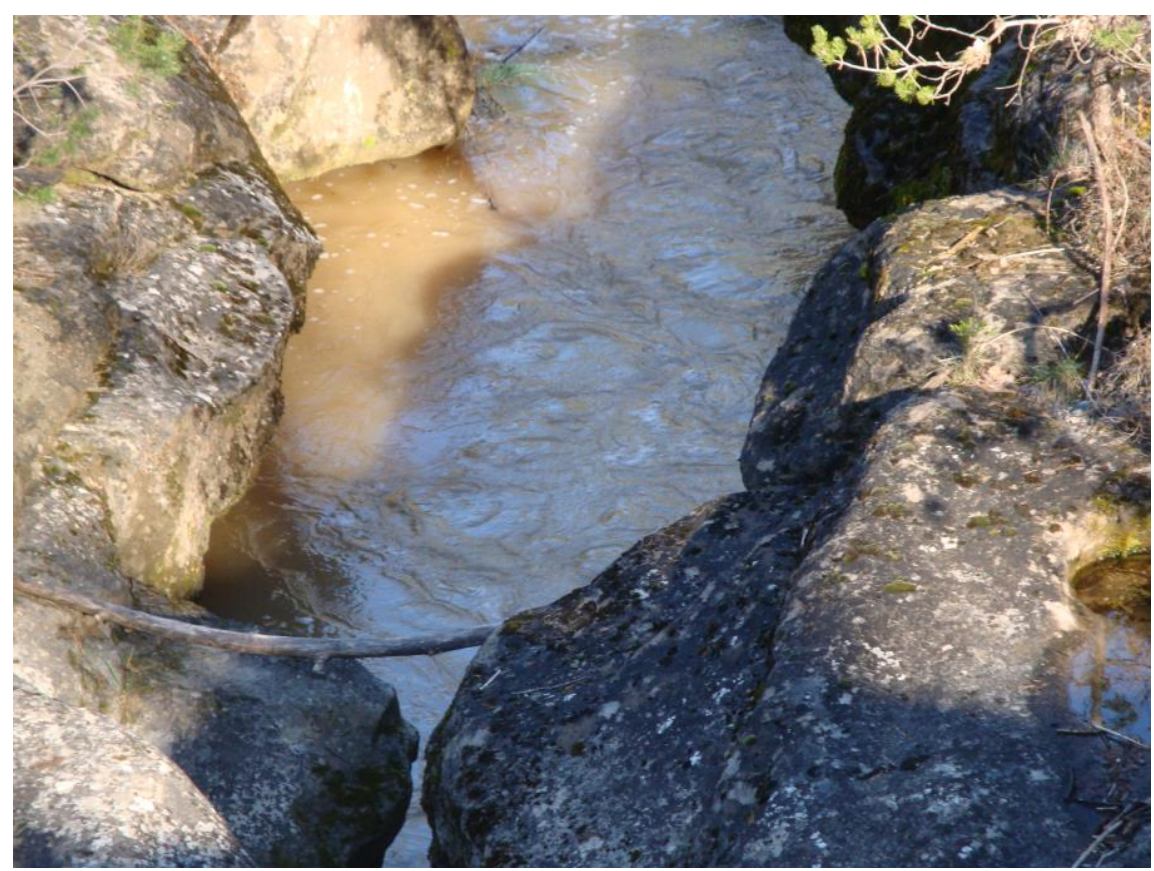

Fotografia 3. Les Goles de Fumanya, a la Riera Gabarresa prop de Sant Martí d’Albars 


\subsection{Parada 4 - condicional. Santuari de la Mare de Deu de Lurdes, (terme municipal de Prats de Lluçanès, comarca d'Osona, subcomarca del Lluçanès). (Full 293).}

A continuació d'efectuar la parada anterior, cal retornar de nou a la carretera local BV - 4341 , per tal d'arribar de nou a la carretera autonòmica $C-62$, finalitzant la fillola que ens a dut a Fumanya. Després, caldrà seguir cap a ponent, amb la intenció d'arribar ara a Prats de Lluçanès (la capital comarcal). Per fer-ho, agafarem el trencall que ens durà directament cap a Prats, la carretera local BP - 4653. Així, just abans d'entrar a la població, trobarem a ma dreta el trencall que ens durà directament al Santuari de la Mare de Deu de Lurdes. Aquí en aquest lloc enlairat, farem una nova aturada, aproximadament, a uns $6 \mathrm{Km}$ de la parada anterior.

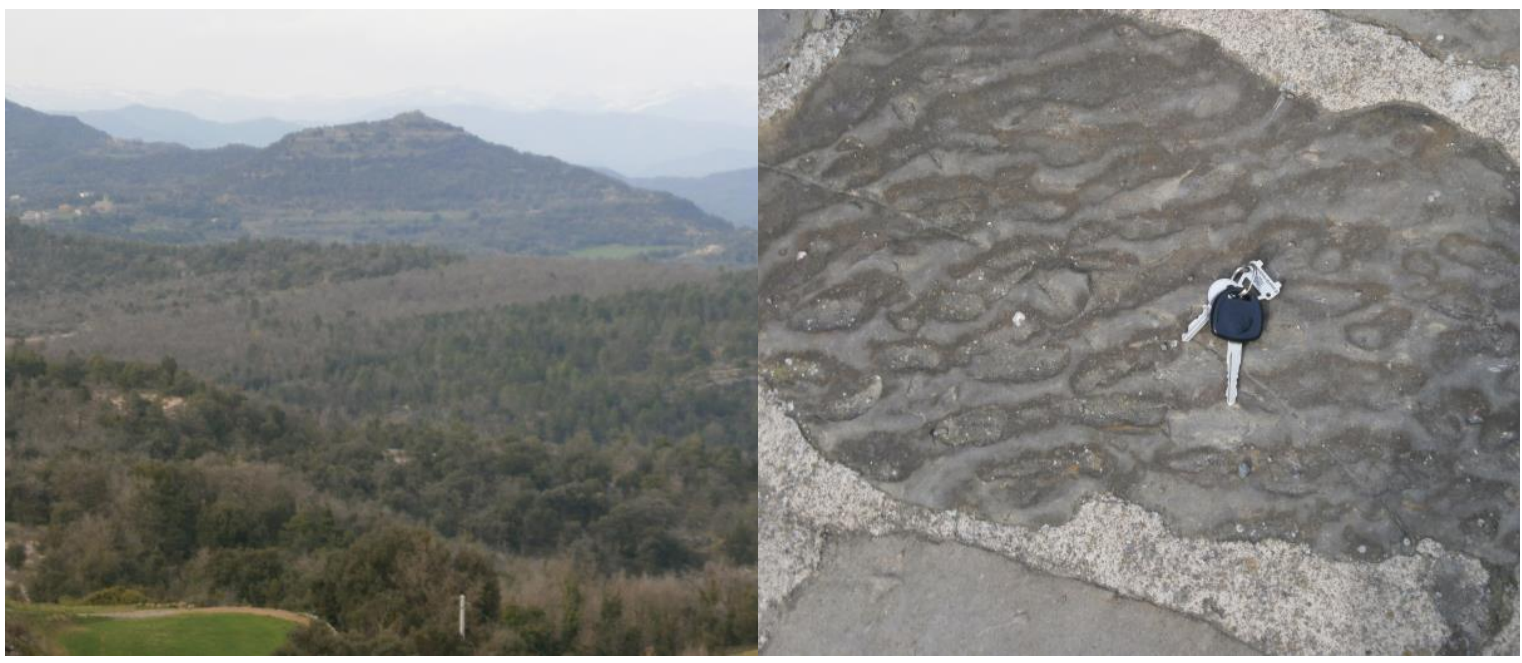

Fotografia 4. El turó del Castell de Lluçà, des del Santuari Fotografia 5. Ripple - marks al camí del Santuari de la de la Mare de Deu de Lurdes (Prats de Lluçanès) Mare de Deu de Lurdes (Prats de lluçanès)

En aquest recorregut, hem anat trobant afloraments dels materials cenozoics (de l'Eocè Superior i de I'Oligocè) que reblen la Depressió Geològica de I'Ebre. Aquests materials es troben constituïts per nivells de gresos i de calcolutites, de tonalitats rogenques i ocres, segons els indrets. Tot i així, predominen els materials rogencs de la Formació Artés. Tot i això, ens trobem en una zona de transició entre aquesta formació i la denominada Formació Solsona Per d'altra banda, cal dir que molt sovint, entre aquests materials hem trobat paleocanals.

Des d'aquest indret, el qual es troba enlairat, es pot gaudir d'un bon lloc d'observació de bona part de la comarca del Lluçanès. Així, mirant cap el Sud es pot veure clarament el turó on es troba el Castell de Lluçà. I més enrere d'ell es veuen els relleus pirinencs. FOTOGRAFIA 4.

Tanmateix, mirant cap a llevant, es veuen els relleus dels voltants d'Olost, Sant Bartomeu del Grau i Sobremunt, entre altres indrets. Mirant cap el Sud, es veuen els relleus dels voltants d'Oristà i fins i tots els del Moianès, la veïna comarca.

Per d'altra banda, mirant al terra, al camí d'accés al Santuari, es poden veure diferents lloses (de les que no sabem la procedència), entre les quals es fàcil veure bons exemples de ripple - marks (també anomenats ondulites). (fotografia 5). 


\subsection{Parada 5. Carretera de Prats de Lluçanès a Oristà, BV - 432, (terme municipal de Prats de Lluçanès, comarca d'Osona, subcomarca del Lluçanès). (Full 293).}

Després de realitzar l'aturada anterior, cal entrar a Prats de Lluçanès, per la carretera que hem agafat, la BP - 4653. Després, des del poble, ens cal fer una nova fillola, agafant ara la carretera local B - 432 (la qual condueix cap al poble d'Oristà). Seguint per aquesta carretera quasi uns $3 \mathrm{Km}$, poc abans d'arribar al límit municipal, farem una nova aturada, a uns 4'5 de la parada anterior, aproximadament.

En aquest recorregut, hem continuat trobant afloraments dels materials esmentats a l'aturada anterior. Efectivament, haurem vist afloraments dels nivells de calcolutites roges $i$ dels nivells de gresos, que en aquest indret pertanyen a la Formació Artés. Molt sovint, hem trobat paleocanals entre els afloraments d'aquests materials.

Així, aquests són els materials que apareixen a l'indret de l'aturada, a tocar amb el terme veí de Sant Martí d'Albars. (fotografia 6).

\subsection{Parada 6 - condicional. Cruilla de les carreteres, de la C - 62 i de la BV - 4406, (terme municipal de Santa Maria de Merlès, comarca del Berguedà, Subcomarca del Lluçanès). (Full 293).}

Després de realitzar la parada anterior, cal retornar cap a Prats de Lluçanès, per tal de sortir cap al NW per la carretera de Lluçà. Fins arribar a la carretera autonòmica C - 62. En trobar-la, anirem cap a ponent, fins arribar a la cruïlla amb la carretera BV - 4406 (Borredà - Merlès). En trobar-la farem una aturada prop de la cruïlla, a uns 9 de la parada anterior.

En aquest recorregut, inicialment hem trobat els materials esmentats a l'aturada anterior. Mes endavant, hem trobat els nivells de gresos i de calcolutites ocres, que formen part de la Formació Solsona. Aquests son precisament els materials que apareixen a l'indret de l'aturada. (fotografia 7).

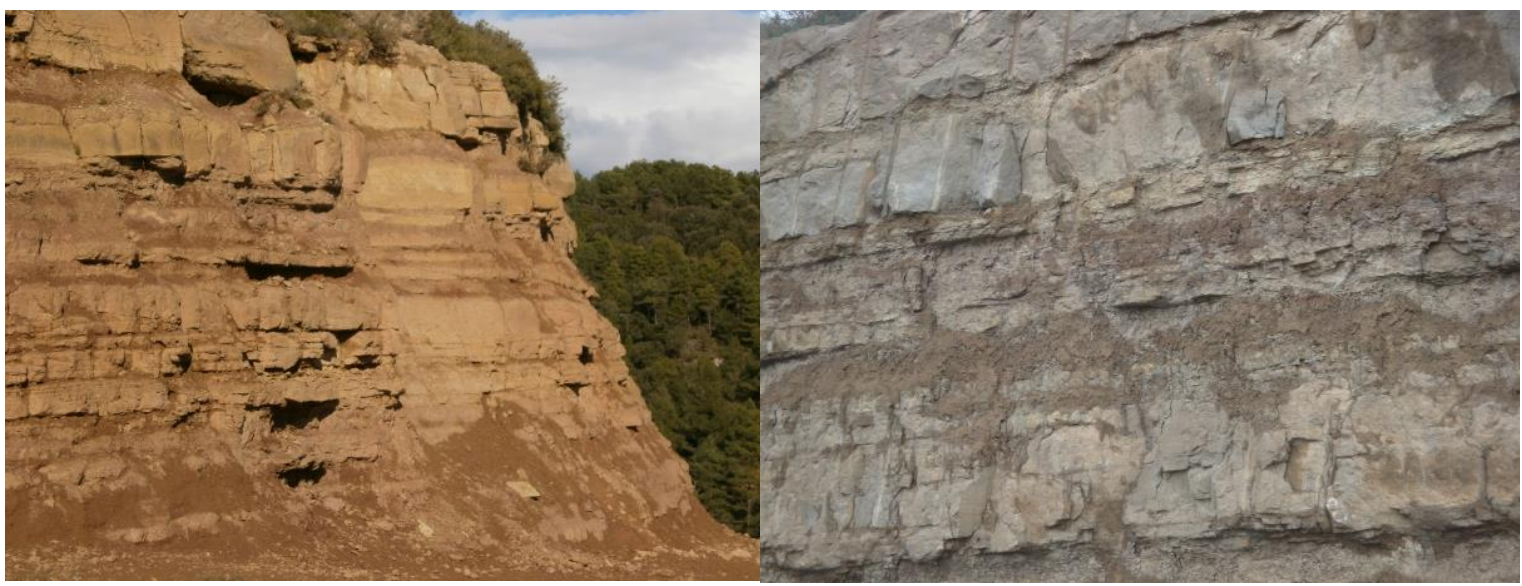

Fotografia 6. Gresos i calcolutites de la Formació Artés.

Fotografia 7 resos i calcolutites de la Formació Solsona. 


\subsection{Parada 7 - condicional. Resclosa de Santa Maria de Merlés, (terme municipal de Santa Maria de Merlès, comarca del Berguedà, subcomarca del Lluçanès). (Full 293).}

Després de realitzar la parada anterior, caldrà continuar anant cap el Sud, fins arribar a Santa Maria de Merlès. En arribar-hi, ens caldrà baixar cap a la Riera de Merlès, per on farem una nova aturada, prop del poblet. Així, des de la parada anterior, haurem recorregut uns $6-7 \mathrm{Km}$, per tal d'arribar fins aquest indret.

En aquest recorregut, hem continuat trobant afloraments dels nivells de gresos i de calcolutites ocres, que formen part de la Formació Solsona, de l'Oligocè. Aquests són els materials de la Depressió Geològica de I'Ebre, els quals es troben a l'indret de l'aturada. En aquest indret hi ha un petit gorg, sobre el qual es va construir una resclosa. (fotografia 8 ).

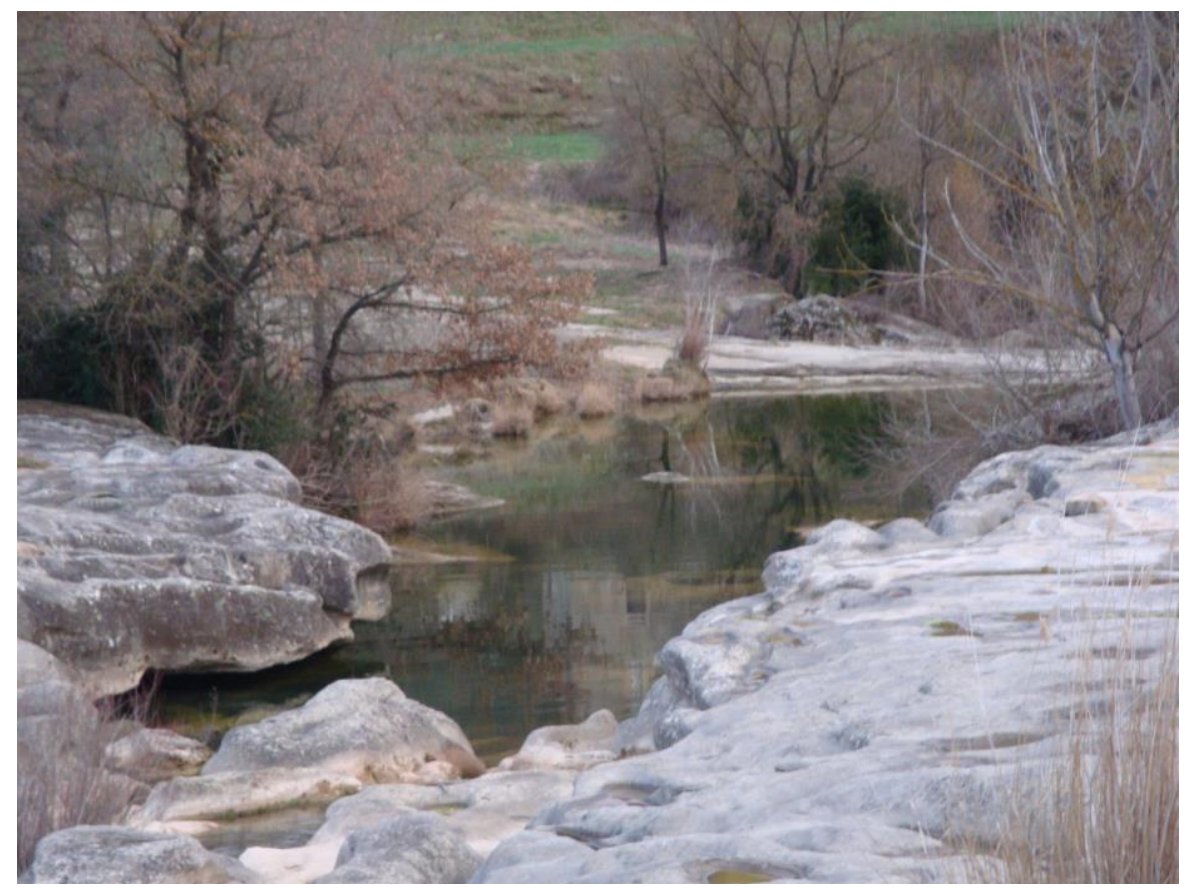

Fotografia 8 El Gorg de la Resclosa de Santa Maria de Merlès, sobre els materials de la Formació Solsona

\subsection{PARADA 8. GORG BLAU, (terme municipal de Santa Maria de Merlès, comarca del Berguedà, subcomarca del lluçanès). (Full 331).}

Després de realitzar la parada anterior, cal efectuar un recorregut per la carretera asfaltada que discorre pel costat septentrional de la Riera de Merlès. Així, s'arribarà a la Fàbrica Nova. Poc després, caldrà seguir per un camí de terra, que va passat d'un marge a l'altre de la riera. Després, en un $3 \mathrm{Km}$ de circulació per aquest camí de terra, s'arribarà al Gorg Blau. En aquest indret, realitzarem una nova aturada, a uns $5 \mathrm{Km}$, aproximadament de l'anterior.

En aquest recorregut, hem continuat trobant afloraments dels materials esmentats a la parada anterior. Efectivament, hem trobat afloraments dels nivells de calcolutites ocres i de gresos, que formen part de la Formació Solsona. Aquests materials reblen la Depressió Geològica de 
I'Ebre, per aquestes contrades. Aquest són també els materials que apareixen a l'indret de la present aturada, on es fa palès un gruix estrat de gresos.

Aquests materials, al llarg d'aquest recorregut, van canviant de cabussament, al travessar diversos plecs. Així, prop de Santa Maria de Merlès, hem travessat el Sinclinal de Gironella i ara estem prop de l'Anticlinal de Puig - reig.

Per d'altra banda, al llarg d'aquest recorregut es fan palesos diferents gorgs, més o menys espectaculars, com el que ara estem veient. Es tracta del Gorg Blau, i es pot considerar com un element important del Patrimoni Geològic, de la comarca del Berguedà. (fotografia 9).

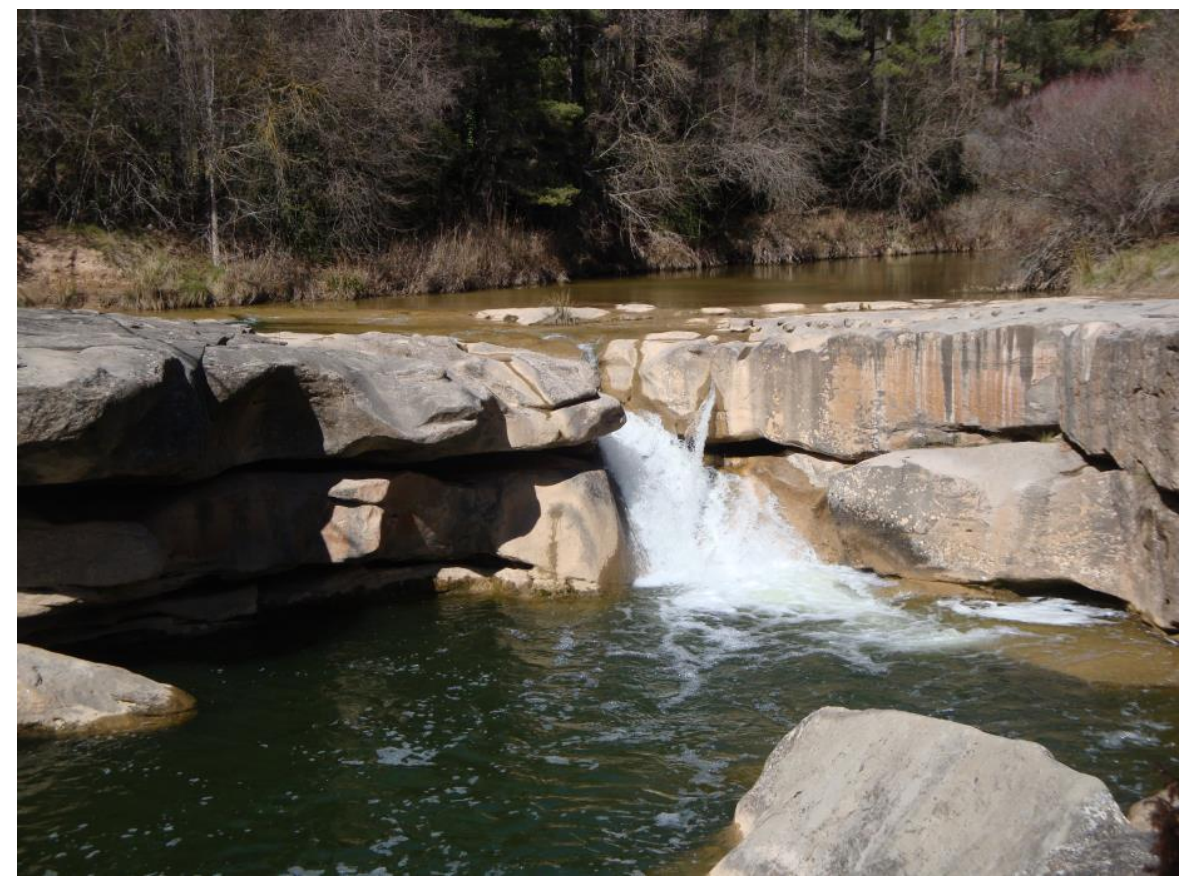

Fotografia 9. El Gorg Blau de la Riera de Merlès, sobre els materials de la Formació Solsona

En aquest indret finalitza el recorregut

\section{Bibliografia}

COLLDEFORNS, B. (1986).- Estudi Geològic de la comarca del Bages. Públic. EUPM, 399 pàgines. Manresa.

GUIMERÀ, J. et altri (1992).- Geologia (II), Història Natural dels Països Catalans, Vol. 2, 547 pag. Enciclopèdia Catalana, S.A. Barcelona.

IGME (1975).- Mapa Geológico de España a Escala 1:50.000 (2ª Sèrie). Full i Memòria $n^{\circ} \underline{363}$ (Manresa). Inst. Tecnológico y GeoMinero de España. Minist. Indus. Ener. Madrid. 
MASACHS, V. et altri (1981).- Itineraris geològics per Anoia, Bages, Berguedà i Solsonès. Pub. Caixa d'Estalvis de Manresa, 205 pag. Manresa.

MATA-PERELLÓ, J.M. (1984).- Els Minerals del Bages i llurs jaciments. Revista Les Fonts, oㅡ 2, pp. 1-32, Manresa.

MATA-PERELLÓ, J.M. (1991).- Els Minerals de Catalunya. Arxius de la Secció de Ciències, t. XCIII, Institut d'estudis Catalans. Barcelona.

MATA-PERELLÓ, J.M. (2013a).- Recorregut de recerca geològica i mineralògica per les comarques del Berguedà, Osona (Lluçanès) i Bages: des de Gironella i la Quar a Lluçà, Prats de Lluçanès, Sant Feliu Sasserra, Avinyó i Artés. Inèdit. 15 pàgines. Manresa

MATA-PERELLÓ, J.M. (2013b).- Recerca geològica i mineralògica per les comarques del Berguedà i del Lluçanès: des de Borredà a Santa Maria de Merlès i a Puig-reig, tot seguint la Riera de Merlès. Inèdit. 18 pàgines. Manresa

MATA-PERELLÓ, J.M. et COLLDEFORNS, B. (1994).- Inventari Mineralògic de la comarca del Bages. Xaragall, no 19, 35 pàgines. Manresa.

MATA-PERELLÓ, J.M. i SANZ BALAGUÉ, J. (1988).- Guia d’Identificació de Minerals (Països Catalans i d'altres). Edit. Parcir, 205 pag. Manresa.

RIBA ARDERIU, O. Et altri. (1976).- Geografia física dels Països Catalans. Edit Ketres. Barcelona. 